\title{
Sacroiliitis and ankylosing spondylitis in North American Indians
}

\author{
J. P. GOFTON, P. H. BENNETT, H. A. SMYTHE, AND J. L. DECKER \\ Vancouver, British Columbia, Canada
}

In studies previously reported a high prevalence of sacroiliitis was demonstrated radiologically in the adult males of the Haida Indian communities on the Queen Charlotte Islands off the northwest coast of British Columbia (Gofton, Robinson, and Trueman, 1966a). Pelvic $x$ rays from other populations were compared with the Haidas in a subsequent study and major geographical differences in the prevalence of $x$-ray evidence of sacroiliitis were shown (Table $\mathrm{I}$ : from Gofton, Lawrence, Bennett, and Burch, 1966b).

Table I Sacroiliitis diagnosed by X ray in adult males from six populations

\begin{tabular}{lrll}
\hline Source & $\begin{array}{l}\text { No. } \\
\text { Examined }\end{array}$ & $\begin{array}{l}\text { Percentage positive } \\
\text { (all grades) }\end{array}$ \\
Haida & 147 & & $9 \cdot 5$ \\
Male relatives* & 93 & & $9 \cdot 7$ \\
Watford & 98 & & $1 \cdot 0$ \\
Blackfeet & 421 & & $2 \cdot 6$ \\
Pima & 355 & & 3.9 \\
Jamaicans (over age 35$) \dagger$ & 80 & & $0 \cdot 0$ \\
\hline
\end{tabular}

* First-degree male relatives age 15 and over of probands with ankylosing spondylitis.

ankylosing spondylitis. ized cases were not included in the survey totals shown here (Lawrence, Bremner, Ball, and Burch, 1966).

A recent survey was undertaken to discover whether the apparently high prevalence of sacroiliitis in the Haidas was confined to this Indian community or was a more widespread phenomenon in the Coastal Indians of British Columbia. Adult males from two further British Columbia coastal communities were examined and $x$-rayed. These films, together with a suitable sample of pelvic $x$ rays from the Pima Indians of Arizona, were compared with the original Haida films.

The grading of $x$ rays for sacroiliitis in the original population comparison (Gofton and others, 1966b) was based on the $x$-ray grading criteria laid down in Rome in 1962 (Table II). The present comparison is based on the revised criteria recommended at the New York Symposium in 1966 (Table III). In the

Table II Rome criteria (1961) for diagnosis of ankylosing spondylitis in population studies (see Bull. rheum. Dis., 1962)

[1] Low back pain and stiffness of over 3 months' duration not relieved by rest.

[2] Pain and stiffness in the thoracic region.

[3] Limited motion in the lumbar spine.

[4] Limited chest expansion.

[5] A history or evidence of iritis or its sequelae

[6] $X$ ray showing bilateral sacroiliac changes characteristic of ankylosing spondylitis (this would exclude bilateral osteoarthritis of the sacroiliac joints). The diagnosis is definite if four of the five clinical Criteria are fulfilled or
if Criterion 6 and one other Criterion are fulfilled. The number of persons fulfilling each separate Criterion or combination of Criteria shall be stated to demonstrate the full extent of disease.

present study a comparison has also been made between these Indian populations for the prevalence of ankylosing spondylitis as defined by the New York criteria. From this experience some comments are offered on the value of the revised $x$ ray and clinical criteria and on the definition of ankylosing spondylitis in these studies by the summation of criteria.

A group of films from three of these Indian populations were graded for sacroiliitis on three separate occasions permitting an evaluation of the consistency of our $x$-ray grading judgments.

\section{Methods}

Populations and sampling methods

(1) BELLA BELLA - the only village on a coastal island about 100 miles from the Haidas. Main occupation fishing, no agriculture. Moist maritime climate. Adult males over age 20 on the reserve list numbered 178.* Examined 158. Completion rate 88 per cent.

(2) BELLA COOLA-a village at the mouth of a major river on the mainland 75 miles from Bella Bella and 175 miles from the Haidas. Main occupations fishing, logging, hunting. Some nearby agriculture in estuary flatland. Moist maritime climate. Adult males over age 15 on reserve list numbered 153. Examined 141. Completion rate 92 per cent.

Accepted for publication April 22, 1972

Address for reprints: J. P. Gofton, M.D., Suite 10-5780 Cambie Street, Vancouver 15, B.C., Canada

* The reserve list is the current record of all registered Indians living on the reserve kept by the Federal Department of Indian Affairs. 
Table III New York criteria (1966) for diagnosis of ankylosing spondylitis and for $x$-ray grading of sacroiliitis in population studies (Bennett and Wood, 1968)

\section{Minimum requirements}

A clinical examination of the back and chest (including measurement of chest expansion) and an antero-posterior radiograph of the pelvis in all males aged $15+$ and in all females aged $45+$ years.

Clinical criteria for ankylosing spondylitis

(1) Limitation of motion of the lumbar spine in all three planes-anterior flexion, lateral flexion, and extension.

(2) A history of or the presence of pain at the dorso-lumbar junction or in the lumbar spine.

(3) Limitation of chest expansion to $1 \mathrm{in} .(2 \cdot 5 \mathrm{~cm}$.) or less, measured at the level of the fourth intercostal space.

Grading of radiographs

The sacroiliac joints on either side should be graded separately

0 Normal

1 Suspicious changes

2 Minimal abnormality - small localized areas with erosion or sclerosis, without alteration in the joint width.

3 Unequivocal abnormality-moderate or advanced sacroiliitis with one or more of: erosions, evidence of sclerosis, widening, narrowing, or partial ankylosis.

4 Severe abnormality - total ankylosis.

For analysis the more severely affected joint should be considered, but a note should be made where the involvement is unilateral.

Application of these criteria

Definite ankylosing spondylitis shall be present if there is Grade 3-4 bilateral sacroiliitis with at least one clinical criterion, or if there is Grade 3-4 unilateral or Grade 2 bilateral sacroiliitis with clinical Criterion 1 or with both clinical Criteria 2 and 3.

Probable ankylosing spondylitis shall be present if there is Grade 3-4 bilateral sacroiliitis without any clinical criteria.

(3) HAIDAS (Data derived from original survey, Gofton and others, 1966a)-Two villages separated by 75 miles on a large offshore island. Occupations fishing, logging, no agriculture. Moist maritime climate. Adult males over age 15 on reserve list numbered 238. Examined 209. Completion rate 88 per cent.

All of these British Columbia Indian peoples represent a condensate in the last 200 years of a much larger population. Admixture of Caucasian genes occurred in all tribes. This was estimated in the Haidas at about 30 per cent (Thomas, Stuckey, Robinson, Gofton, Anderson, and Bell, 1964). Some admixture of genes occurred between the three tribes in early days as the result of raiding. Otherwise these three communities have distinct languages and separate traditions.

(4) PIMAS-an agricultural community in the semi-arid desert of Arizona, U.S.A. Occupation mainly agriculture. Adult males over age 15 numbered 1402. Examined 1157. Completion rate 77.5 per cent.

For the present study an age stratified random sample of 223 films and records were drawn to compare in age distribution with the other Indian populations.

It is known that Caucasian genes have been introduced into the Pima stock. Published studies (Matson, Burch, Polesky, Swanson, Sutton, and Robinson, 1968) and historical data suggest that there is less admixture of Caucasian genes in the Pima Indians than there is in the British Columbia Indians. It is of interest that the Blackfeet Indians (Table I) probably have the least admixture of Caucasian genes as well as less sacroiliitis and ankylosing spondylitis than either the Pimas or the Haidas.

\section{Radiography and clinical examinations}

An antero-posterior $x$ ray of the pelvis was available on all respondents. Clinical data were available and were appropriate to the New York criteria (Bennett and Wood, 1966). Clinical examination of respondents was carried out by a variety of physicians at different times although one of us (J.P.G.) was directly concerned with all of the clinical examinations in the British Columbia Indians.

\section{$X$-ray grading procedures}

All films were mixed together randomly after identification marks had been obscured as far as possible. A specific 'Reading Code No.' was assigned with a china-marking pencil over one femoral head.

Films were graded in a two-phase procedure by all four authors at a single session.

Initially each reader acting individually graded all films and made a tentative decision according to the New York grading criteria (Table III).

\section{0 -normal}

1-suspicious changes ('uncertain')

2-minimal abnormality ('probable' sacro-iliitis)

3 or 4-unequivocal or severe abnormality ('definite sacro-iliitis)

In this first phase emphasis was placed on identification of negative or normal films. Films considered to be abnormal were assigned a tentative grade by the reader with the knowledge that a firm grade would be assigned later in the second phase or group reading session. When all films had been graded by each individual those which were read by everyone as negative were discarded. 
All films read as Grade 1, 2, 3, or 4 by any reader were segregated and the group of readers considered these together assigning a group or 'reconciled' grade. This procedure allows concentrated attention to be given to the positive and difficult $x$-ray films which usually amount to less than 20 per cent. of the total.

Although all identification marks could not be completely obscured, in the reading process described, it was found that the reader's attention was focused on the sacro-iliac joints and on the reading code number. It is believed that the source of the film had no influence on the final grading assigned.

442 films from the British Columbia Indian populations were available for two preliminary reading sessions when two or more members of the group were present.

\section{Results}

Table IV displays the prevalence of sacroiliitis by $x$ ray, in the four Indian populations, shown in three separate age segments to permit comparison between the populations and with data to be presented later. The age group 15 to 20 in Bella Bella was not examined as over half of these young men were away at school.

Although there are some differences between the populations in the prevalence of sacroiliitis, the only difference of statistical significance is the Haida-Pima comparison for Grade 3-4 sacroiliitis age 15 and over $(\mathrm{P}<0.05)$.

None of the differences between the populations in the prevalence of ankylosing spondylitis, defined by the New York criteria, is statistically significant (Table V).
There is some suggestion from these data that the Haidas and Bella Bellas have a similar high prevalence of sacroiliitis and of ankylosing spondylitis, whereas the Bella Coolas and Pimas are somewhat lower. The number of respondents examined is insufficient to make the differences statistically significant.

\section{Discussion}

Sufficient evidence has now accumulated to define major geographical differences in the prevalence of ankylosing spondylitis if clearcut radiological evidence of sacroiliitis defines the disease. Objections may be raised to this definition.

Sacroiliitis is known to occur in association with diseases other than straightforward ankylosing spondylitis. Sacroiliitis, by $x$ ray, is found in roughly 20 per cent of patients with ulcerative colitis (Wright and Watkinson, 1965), or in psoriasis (Wright, 1961). The prevalence of radiological sacroiliitis in the B.C. Indians is in the general order of 10 per cent. If a similar relationship holds between sacroiliitis and such 'related' diseases in these people then some 50 per cent of the males should be affected by one or other of the 'related' diseases. Only one case of psoriasis was ever seen in all the B.C surveys and that occurred in a middle aged man with negative sacro iliac joints (psoriasis is a rare disease in Nort American Indians). Physicians who regularly serve the three B.C. Indian communities have no recollec: tion of a single case of ulcerative colitis or regional ileitis.

The prevalence of sacroiliitis in Reiter's syndrome is probably higher than in psoriasis or ulcerative

Table IV Percentage prevalence of sacroiliitis by $x$ ray in males, by age

\begin{tabular}{|c|c|c|c|c|c|c|c|c|c|}
\hline \multirow[t]{2}{*}{ Age (yrs) } & \multicolumn{3}{|l|}{$15+$} & \multicolumn{3}{|l|}{$20+$} & \multicolumn{3}{|l|}{$25+$} \\
\hline & $\begin{array}{l}\text { Grades } 2,3,4 \\
\text { (per cent.) }\end{array}$ & $\begin{array}{l}\text { Grades } 3,4 \\
\text { (per cent.) }\end{array}$ & $\begin{array}{l}\text { Popula- } \\
\text { tion }\end{array}$ & $\begin{array}{l}\text { Grades } 2,3,4 \\
\text { (per cent.) }\end{array}$ & $\begin{array}{l}\text { Grades } 3,4 \\
\text { (per cent.) }\end{array}$ & $\begin{array}{l}\text { Popula- } \\
\text { tion }\end{array}$ & $\begin{array}{l}\text { Grades } 2,3,4 \\
\text { (per cent.) }\end{array}$ & $\begin{array}{l}\text { Grades } 3,4 \\
\text { (per cent.) }\end{array}$ & $\begin{array}{l}\text { Popula- } \\
\text { tion }\end{array}$ \\
\hline $\begin{array}{l}\text { Haida } \\
\text { Bella Bella* } \\
\text { Bella Coola } \\
\text { Pima }\end{array}$ & $\begin{array}{l}11 \cdot 0 \\
9 \cdot 2 \\
6 \cdot 7\end{array}$ & $\begin{array}{l}\frac{8 \cdot 1}{3 \cdot 5} \\
3 \cdot 1\end{array}$ & $\begin{array}{l}209 \\
\overline{141} \\
223\end{array}$ & $\begin{array}{r}11 \cdot 4 \\
11 \cdot 4 \\
11 \cdot 0 \\
8 \cdot 4\end{array}$ & $\begin{array}{l}8 \cdot 0 \\
7 \cdot 6 \\
4 \cdot 6 \\
4 \cdot 2\end{array}$ & $\begin{array}{l}175 \\
158 \\
109 \\
166\end{array}$ & $\begin{array}{r}13 \cdot 6 \\
13 \cdot 0 \\
9 \cdot 4 \\
9 \cdot 2\end{array}$ & $\begin{array}{l}9 \cdot 5 \\
9 \cdot 2 \\
5 \cdot 2 \\
4 \cdot 5\end{array}$ & $\begin{array}{r}147 \\
131 \\
96 \\
153\end{array}$ \\
\hline Total popula & & & 573 & & & 608 & & & 427 \\
\hline
\end{tabular}

- Age group 15 to 20 years not examined.

(Grades 2, 3, 4 include-bilateral Grade 2 and unilateral Grade 3-4 but excludes unilateral Grade 2).

Table V Percentage definite and probable ankylosing spondylitis (New York 1966 criteria) in males, by age

\begin{tabular}{|c|c|c|c|c|c|c|}
\hline \multirow[t]{2}{*}{ Age (yrs) } & \multicolumn{2}{|l|}{$15+$} & \multicolumn{2}{|l|}{$20+$} & \multicolumn{2}{|l|}{$25+$} \\
\hline & Definite & Probable & Definite & Probable & Definite & Probable \\
\hline $\begin{array}{l}\text { Haida } \\
\text { Bella Bella } \\
\text { Bella Coola } \\
\text { Pima }\end{array}$ & $\begin{array}{l}4 \cdot 7 \\
2 \cdot 1 \\
4 \cdot 5\end{array}$ & $\begin{array}{l}2 \cdot 4 \\
1 \cdot 4 \\
2 \cdot 2\end{array}$ & $\begin{array}{l}6 \cdot 0 \\
6 \cdot 3 \\
2 \cdot 7 \\
5 \cdot 4\end{array}$ & $\begin{array}{l}2 \cdot 9 \\
1 \cdot 3 \\
1 \cdot 8 \\
3 \cdot 0\end{array}$ & $\begin{array}{l}6 \cdot 7 \\
7 \cdot 6 \\
3 \cdot 1 \\
5 \cdot 9\end{array}$ & $\begin{array}{l}2 \cdot 7 \\
1 \cdot 5 \\
2 \cdot 1 \\
3 \cdot 3\end{array}$ \\
\hline
\end{tabular}


colitis (Good, 1965; Wright and Reed, 1964). This syndrome is more difficult to document or to discount in this kind of survey. However Reiter's syndrome is a relatively uncommon disease and as with the other 'related' diseases has not been seen or recognized by the physicians who live among these communities and care for the people.

Unless one postulates a widespread 'related' disease in an occult form, the high prevalence of sacroiliitis can scarcely be attributed to this source.

Many cases of typical clinical ankylosing spondylitis were seen in these people associated with welldefined radiological sacroiliitis. The onset and course of the disease were similar to that found in Caucasian patients. In addition some women were also shown to have sacroiliitis and typical ankylosing spondylitis.

We believe the high prevalence of sacroiliitis in these communities is largely, if not completely, due to ankylosing spondylitis.

Although the comparisons shown in Table VI are somewhat compromised by different $x$-ray reading criteria the outstanding differences in the prevalence of sacroiliitis between the B.C. Indians and the Jamaicans and Watford communities, for instance, can scarcely be denied.

Table VI Percentage definite sacroiliitis in various populations of males over 25 years old

\begin{tabular}{|c|c|c|c|}
\hline Population & $\begin{array}{l}\text { No.of } \\
\text { Films }\end{array}$ & $\begin{array}{l}\text { This Study } \\
\text { Grade 3-4 }\end{array}$ & $\begin{array}{l}\text { Previous Study } \\
\text { Grade } 2-3-4\end{array}$ \\
\hline $\begin{array}{l}\text { Bella Bella } \\
\text { Bella Coola } \\
\text { Haida } \\
\text { Pima } 1 \\
\text { Pima 2 } \\
\text { Blackfeet } \\
\text { Watford } \\
\text { Male relatives } \\
\text { Jamaicans (over age 35) }\end{array}$ & $\begin{array}{r}131 \\
96 \\
147 \\
355 \\
153 \\
421 \\
98 \\
93 \\
80\end{array}$ & $\begin{array}{l}9 \cdot 2 \\
5 \cdot 2 \\
9 \cdot 5 \\
\\
4 \cdot 5\end{array}$ & $\begin{array}{l}9.5 \\
3.9 \\
\\
2.6 \\
1.0 \\
9 \cdot 7 \\
0.0\end{array}$ \\
\hline
\end{tabular}

This Table compares the percentage of definite sacroiliitis found in this study in four populations with the results of a previous population comparison (Gofton and others, 1966b). The grading 2-3-4 from the previous study is not exactly comparable with Grade 3-4 in this study. It is interesting that the Haida films showed the same percentage positive at two different comparisons, several years apart by a different group of readers. A comparison of individual films reveals that there is complete agreement in all but one film in each study. The estimation of the prevalence of sacroiliitis in the Pima males was evaluated by a comprevalencer of sacroilitis in the Pima males was pletely different set of films in the two studies. There is a slight difference reasonable consistency in this method of assessing a population for reasonable

Male relatives refers to first-degree male relatives of probands with ankylosing spondylitis.

Studies by Muller and Valkenberg (1970) on Liberian and Nigerian natives suggest that sacroiliitis and ankylosing spondylitis are present, but the disease is mild and of low prevalence. Although other estimates of the prevalence of ankylosing spondylitis have been made (Julkunen, 1962; West, 1949; Baum and Ziff, 1971) they are of uncertain validicy and do not lend themselves to comparisons with the studies reported here.

No useful hypothesis has so far been suggested to explain these differences. There are environmental contrasts between the Pima and the B.C. Indian communities. One of the most obvious is climatic. To our knowledge there have been no comparable surveys of Caucasian populations living in maritime environments.

There is an apparent gradient of sacroiliitis in these Indian communities from high in the Haidas to low in the Blackfeet. As mentioned earlier there may be a similar gradient in the admixture of Caucasian genes again high in the Haidas and low in the Blackfeet. Whether the Caucasian admixture of genes has influenced the prevalence of sacroiliitis in any of these people is open to speculation.

CRITERIA FOR DIAGNOSIS-X RAY

The Standard Atlas of Radiographs (1963) describes and illustrates Grade 2, 3, and 4 sacroiliitis (Table II). Although it may not have been so intended Grade 2 not only defines instances of clearcut sacroiliitis without ankylosis but is also the only grade assignable to a borderline $x$ ray which is finally designated as abnormal. Thus Grade 2 includes unequivocal sacroiliitis as well as 'probable' sacroiliitis as judged by the reader. The revised criteria for $x$-ray grading set down at the New York Symposium (Table III) recognize this problem and designate Grade 2 as minimal abnormality (i.e. probable), reserving Grade 3 for all instances of clearcut disease whether or not partial ankylosis is present. These revised gradings tend to refer to the degree of conviction by the reader rather than to severity of disease. Grade 4 serves no useful purpose in the diagnosis of sacroiliitis by $x$ ray, simply denoting a totally fused joint. In the sense that Grade 2 now represents 'probable', whereas Grade 3 and 4 are now 'definite', this revised grading process has clarified some confusion and was found to be useful.

Films which are difficult to grade fall into several categories. It is our experience that one's ability to grade $x$ rays for sacroiliitis improves greatly after a trial or training session. The major effect of this is to bring the reader to recognize a number of conditions and artefacts which suggest that the sacroiliac joint is abnormal, and which he may not have studied in a concentrated way before.

The juvenile sacroiliac joint is a major problem. The aged pelvis may also be troublesome. In both instances it has proven to be helpful to have the age of the respondent available at the grading process. A mildly sclerotic somewhat irregular joint at age 75 is not sacroiliitis of the kind we are looking for; a similar joint at age $\mathbf{3 0}$ is almost certainly abnormal. The widened ill-defined and irregular normal juvenile sacroiliac joint seen in young respondents is often associated with epiphyseal immaturity in the ilium, femur, or pelvis which aids in the interpretation. But an immature sacroiliac joint may also be 
seen in young respondents where the pelvis is apparently mature and epiphyseal closure elsewhere has occurred. If the respondent is age 21 or under we consider such a sacroiliac joint to be normal. Typical sacroiliitis in juvenile sacroiliac joints shows gross irregularity and widening (Carter and Loewi, 1962).

Overlying gas and faecal shadows are common in films derived from a survey of this kind and may mislead the inexperienced reader. Once these artefacts are recognized the underlying joints can be read with reasonable confidence.

At the final group reading session agreement was usually reached without difficulty. Most films read as Grade 3 or 4 were recognized as such by everyone. Some variations occurred in the Grade 2 category which reflects its definition by the revised criteria. It was rare to find genuine disagreement between members requiring a majority vote for a final decision.

Two or three films in the Haida series have always proved difficult to interpret. They have been read on numerous occasions by a number of observers, who have graded these films on more than one occasion. No consensus has ever been obtained on these films, the decision usually being that the $x$ ray is either Grade 3 or is normal. A number of respondents with difficult pelvic $x$ rays from the original 1964 Haida survey were followed up at a later date and re- $x$ rayed. Careful technique was used usually with oblique views of the pelvis. In most instances further $x$ rays supported the opinion that the sacro-iliac joints were probably normal. In the $x$-ray grading of abnormality presented here the decisions were conservative, the films in general being under-read when doubt existed.

Macrae, Haslock, and Wright (1971) graded sacroiliac joints specifically for sclerosis, erosions, and joint width, and concluded that sclerosis was the most useful parameter and joint width of little value. We agree that separate scoring for individual features complicates the process of grading and does not assist in the final decision. As far as population comparisons are concerned an overall opinion of the sacroiliac joints expressed as negative, 'probable' and 'definite' expressing a degree of conviction, seems to be the most useful basis for comparison.

CRITERIA FOR DIAGNOSIS-CLINICAL

For the purpose of defining differences in the prevalence of disease between populations the epidemiological criteria for the diagnosis of ankylosing spondylitis laid down in Rome accepted evidence of sacroiliac disease by $x$ ray together with some supporting clinical evidence. On the other hand, a diagnosis of ankylosing spondylitis was also acceptable if the full array of clinical findings was present, even if $x$-ray findings were negative (Table II). This definition poses some difficulties which have been summarized elsewhere (Bennett and Wood, 1966). In the studies reported here, a major conceptual problem involved respondents where clinical criteria were absent in the face of unequivocal $x$-ray evidence of sacroiliitis. By these criteria ankylosing spondylitis could not be diagnosed. Furthermore many of the clinical criteria laid down in Rome were obtainable only by history and were of uncertain reliability (e.g. iritis).

In New York the sub-committee agreed that for epidemiological purposes the diagnosis of ankylosing spondylitis should not be made without $x$-ray evidence of sacroiliitis. As in Rome they required some supporting clinical evidence no matter what severity of disease was seen on $x$ ray. Clinical criteria were revised in an attempt to make them more objective (Table III). Some difficulties have also been encountered with these new criteria for ankylosing spondylitis when they were applied to the present studies. In the Indian populations it is not rare to find advanced sacroiliitis on $x$ ray, often with confirmatory evidence in the spine, in the face of negative history, good chest expansion and a spine which is acceptably mobile (by any standard). Thus five of fifteen Haidas with Grade 3 or $4 x$ rays showed no clinical evidence of ankylosing spondylitis as defined here (Table VII). The clinical criteria specified at New York are not sensitive to what appears to us too be ankylosing spondylitis in these people. In our? respondents additional symptoms or signs of musculo-skeletal problems were in no way specific (Table VII). On these grounds it does not appear to us that the addition of further clinical criteria would assist in solving the problem.

Another difficulty is found where the spectrum of relevant (by New York Criteria) clinical findings is quite different in the various populations in those respondents with negative findings by $x$ ray (Table VIII). Limitation of the lumbar spine was a frequent finding in $x$-ray negative Pimas, was not infrequent in Bella Bella, but was not found in $x$-ray negative Bella Coolas or Haidas. What does this reflect? We believe there is some variation in the estimation of limitation of the lumbar spine between observers, in spite of prior discussions about the criterion. We infer that it is unsafe to use this criterion in studies where different clinical observers are taking part. A method of measuring spinal mobility (Moll and Wright, 1971) would diminish the error. However, the problem has another aspect which would not be solved by elimination of inter-observer variation alone. The Pimas show a great deal of unequivocal spinal limitation unrelated to $x$-ray evidence of sacroiliitis or other evidence of ankylosing spondylitis. In these people limitation of the lumbar spine is commonly associated with an inordinate amount of senile ankylosing hyperostosis. 
Table VII Respondents with sacroiliitis by $x$ ray with and without clinical criteria

\begin{tabular}{|c|c|c|c|c|c|}
\hline $\begin{array}{l}\text { Group } \\
\text { Grade }\end{array}$ & Population & Total No. & $\begin{array}{l}\text { No. with positive } \\
\text { N.Y. criteria }\end{array}$ & $\begin{array}{l}\text { No clinical } \\
\text { findings }\end{array}$ & Other clinical data not relevant to $N . Y$. criteria \\
\hline $\begin{array}{l}3-4 \\
\text { positive }\end{array}$ & $\begin{array}{l}\text { Haida } \\
\text { Pima } \\
\text { Bella Bella } \\
\text { Bella Coola }\end{array}$ & $\begin{array}{l}15 \\
7 \\
12 \\
6 \text { (1 unilateral) }\end{array}$ & $\begin{array}{r}10 \\
3 \\
9 \\
3\end{array}$ & $\begin{array}{l}5 \\
3 \\
2 \\
3\end{array}$ & $\begin{array}{l}\text { None } \\
1 \text { Past history polyarthritis } \\
1 \text { History swollen knees } \\
1 \text { Unilateral septic sacroiliitis } \\
1 \text { Knee pain } \\
1 \text { Buttock pain }\end{array}$ \\
\hline $\begin{array}{l}\text { Bilateral } \\
\text { Grade } 2 \\
\text { positive }\end{array}$ & $\begin{array}{l}\text { Haida } \\
\text { Pima } \\
\text { Bella Bella } \\
\text { Bella Coola }\end{array}$ & $\begin{array}{l}6 \\
7 \\
6 \\
8\end{array}$ & $\begin{array}{l}3 * \\
6 \dagger \\
2 \\
4\end{array}$ & $\begin{array}{l}3 \\
1 \\
4 \\
4\end{array}$ & $\begin{array}{l}\text { None } \\
\text { None } \\
\text { None } \\
\text { None }\end{array}$ \\
\hline
\end{tabular}

* One of three Haidas had limitation of lumbar spine.

+ Five of six Pimas had limitation of lumbar spine.

No Bella Bella or Bella Coola bilateral Grade 2 had limitation of lumbar spine.

Table VIII Sacroiliitis and New York clinical criteria in males aged 20+

\begin{tabular}{|c|c|c|c|c|c|c|c|c|c|}
\hline \multirow[t]{2}{*}{ Population } & \multicolumn{4}{|c|}{ With positive $x$ rays (Grade $2,3,4)$} & \multicolumn{4}{|c|}{ With negative $x$ rays } & \multirow[t]{2}{*}{ Total } \\
\hline & No. & Limit.L.Spine & Hist.B.Pain & Limit. Chest & No. & Limit.L.Spine & Hist.B.Pain & Limit. Chest & \\
\hline Haida & 21 & 9 & 11 & 6 & 154 & 0 & 20 & 0 & 175 \\
\hline Pima & 14 & 12 & 7 & 7 & 152 & 35 & 52 & 30 & 166 \\
\hline Bella Coola & 12 & 0 & 6 & 1 & 97 & 0 & 34 & 4 & 109 \\
\hline Bella Bella & 18 & 7 & 11 & 8 & 140 & 8 & 21 & 0 & 158 \\
\hline
\end{tabular}

Thus, from our studies in these people, clinical criteria for the diagnosis of ankylosing spondylitis are neither specific nor sensitive.

In both the Rome and New York criteria the diagnosis of ankylosing spondylitis is based on the summation of criteria. At New York it was thought that a Grade 2 sacroiliitis (i.e. 'probable'), if combined with the clinical finding of limitation of the lumbar spine was so characteristic of ankylosing spondylitis that the respondent could safely be defined as having the disease. In the populations we report the assumption seems to be invalid. Thus the Pimas have as much ankylosing spondylitis, defined in this way, as do the Haidas although they have much less Grade 3 or 4 sacroiliitis. The difference is attributable to a large number of Pimas with Grade 2 sacroiliitis by $x$ ray who had limitation of the lumbar spine and therefore achieved a diagnosis of ankylosing spondylitis.

In our opinion the diagnosis of ankylosing spondylitis by the summation of criteria is an interesting exercise but has little value beyond this. It is unlikely that all of the uncertainty in the $x$-ray diagnosis of sacroiliitis, or in the evaluation of clinical data, can ever be removed. For this reason small differences in the prevalence of sacroiliitis, or ankylosing spondylitis, between populations will be suspect. Major differences in the prevalence of unequivocal sacroiliitis however can probably be taken to reflect true differences in the prevalence of ankylosing spondylitis, if adequate account is taken of the possible contribution of 'related' diseases mentioned previously.

CONSISTENCY OF X-RAY GRADING

Table IX (overleaf) shows our experience with 442 pelvic films read at three separate sessions, by the $x$-ray grading process described, by two or more readers. Session B was probably 'oversensitive'. The differences in prevalence between the three communities were maintained and the three final prevalences of sacroiliitis were not grossly different. As a simple expression of experience one would have some confidence that major differences in the prevalence of sacroiliitis between communities would not escape discovery by the process of grading described, albeit some uncertainty and variability in grading some films is present and probably inescapable.

\section{Conclusions}

(1) A gradient of sacroiliitis and presumably of ankylosing spondylitis as defined here appears to exist between coastal B.C. Indians through Pimas and Blackfeet to Caucasian and Negroid communities in England and Jamaica. Statistical significance is present only between the extremes of the gradient.

(2) The data available do not allow more than speculation on the possible contribution of racial, genetic, or environmental factors to the appearance 
Table IX Comparison of $x$-ray grades on 442 films at three separate grading sessions
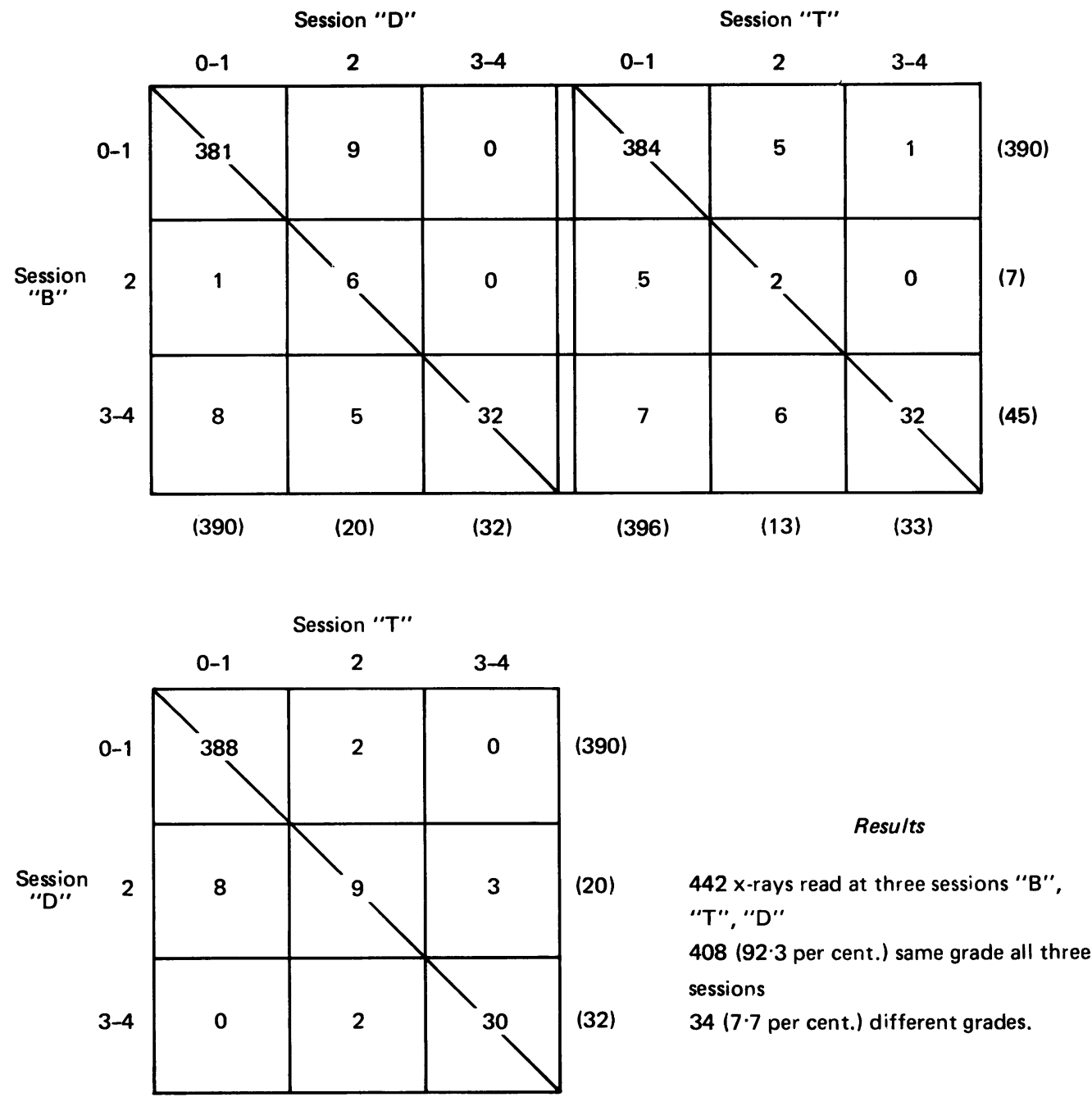

(396)

(13)

(33)

of the disease. The apparent differences in the contribution of Caucasian genes to the Indian populations is of interest but its significance cannot be determined.

(3) Further surveys for sacroiliitis in selected populations may define important differences in prevalence pointing the way towards investigations relevant to aetiological possibilities, and such studies should be encouraged.

We should like to acknowledge the kindness and cooperation of the people of Masset, Skidegate, Bella Bella, and Bella Coola, without which these studies would not have been possible. We are grateful to Dr. Ian Chisholm, Bella Coola, Dr. Roger Page, Bella Bella, and to various doctors including Dr. Bram Bernstein, and the staff at the United Church Hospitals in the three areas. We also acknowledge the assistance of Jean Meakin, Sheila Manning, and Margaret Coggreve in these studies.

\section{References}

Atlas of Standard Radiographs of Arthritis (1963) 'Epidemiology of Chronic Rheumatism', vol. 2. Blackwell, Oxford BAUM, J., AND ZIFF, M. (1971) Arthr. and Rheum., 14, 12, (The rarity of ankylosing spondylitis in the Black race) BenNETT, P. H., AND Wood, P. H. N. (ed.) (1968) Report from the Subcommittee on Diagnostic Criteria for Ankylosing Spondylitis (chairman J. P. Gofton) in 'Population Studies of the Rheumatic Diseases', Proc. 3rd Int. Symp., New York (1966), p. 314. Int. Congr. Ser. No. 148. Excerpta Medica Foundation, Amsterdam 
Carter, M. E., AND Loewi, G. (1962) Ann. rheum. Dis., 21, 121 (Anatomical changes in normal sacro-iliac joints during childhood and comparison with changes in Still's disease)

Gofton, J. P., LAWrence, J. S., Bennett, P. H., AND BuRCh, T. A. (1966b) Ibid., 25, 528 (Sacro-iliitis in eight populations)

—, Robinson, H. S., AND Trueman, G. E. (1966a) Ibid., 25, 525 (Ankylosing spondylitis in a Canadian Indian population)

Good, A. E. (1965) Acta rheum. scand., 11, 305 (Reiter's disease and ankylosing spondylitis)

JuLKUNEN, H. (1962) Ibid., Suppl. 4, p. 12 (Rheumatoid spondylitis)

LaWrence, J. S., Bremner, J. M., Ball, J., AND BurCh, P. A. (1966) Ann. rheum. Dis., 25, 59

MACRAE, F., HASLOCK, D. I., AND WRIGHT, V. (1971) Ibid., 30, 58 (Grading of films for sacro-iliitis in population studies)

Matson, G. A., Burch, T. A., Polesky, H. F., Swanson, J., Sutton, H. E., and Robinson, A. (1968) Amer. J. phys. Anthrop., 29, 311 (Distribution of hereditary factors in the blood of Indians of the Gila River, Arizona)

Moll, J. M. H., AND WRIGHT, V. (1971) Ann. rheum. Dis., 30, 381 (Normal range of spinal mobility)

Muller, A. S., AND Valkenburg, H. A. (1970) 'Population Studies on the Prevalence of Rheumatic Diseases in Liberia and Nigeria'. Drukkerij J. H. Pasmans,-'s Gravenhage

Rome Criteria, 1961 (1962) Bull. rheum. Dis., 13, No. 3, November

Thomas, J. W., Stuckey, M. A., Robinson, H. S., Gofton, J. P., Anderson, D. O., ANd Bell, J. N. (1964) Amer. J. phys. Anthrop., 22, 189 (Blood groups of the Haida Indians)

WEST, H. F. (1949) Ann. rheum. Dis., 8, 143 (The aetiology of ankylosing spondylitis)

WRIGHT, V. (1961) Ibid., 20, 123 (Psoriatic arthritis)

AND REED, W. B., (1964) Ibid., 23, 12 (The link between Reiter's syndrome and psoriatic arthritis)

- AND WATKINSON, G. (1965) Brit. med. J., 2, 670 (Arthritis of ulcerative colitis) 